\title{
MERKLOVO OBECNÉ PRÁVO SPRÁVNÍ A POŠVÁŘOVY OBECNÉ POJMY SPRÁVNÍHO PRÁVA V KOMPARATIVNÍM POHLEDU
}

\author{
PAVEL MARŠÁLEK
}

\begin{abstract}
General Administrative Law by Merkl and General Concepts of Administrative Law by Pošvář in a comparative view

The paper compares two books: the celebrated General Administrative Law by Merkl and the half-forgotten General Concepts of Administrative Law by Pošvár. Their authors espouse normativism: As for Merkl, its Viennese branch; and Pošvár, the Brno branch. They do so undogmatically. Both works are up to a high standard, although Merkl's work has the character of a monograph and that of Pošvár̆ is propaedeutic. Differences between them largely lie in their scope, thoroughness of treatment and circumstances in which they were written. Some differences of opinion are also noticeable. What matters is that these books can be used as a source of information and inspiration although the world and administrative studies have since covered a great distance.
\end{abstract}

Keywords: normativism, pure theory of law, administrative law, administrative studies, history of administrative studies

Klíčová slova: normativismus, ryzí nauka právní, správní právo, správní věda, dějiny správní vědy

DOI: $10.14712 / 23366478.2017 .27$

\section{SMYSL A HODNOTA KOMPARACE MERKLOVY A POŠVÁŘOVY PRÁCE}

Habent sua fata libelli (knihy mají své osudy), napsal kdysi Terentianus Maurus. Narážel na to, že některé vstoupí do historie, jiné upadnou do zapomenutí. Vše v závislosti na tom, jak je přijmou čtenáři: zda je čtou nebo nikoli. Proč si nějaké dílo dobude proslulost a jiné skončí zapomenuto, bude asi záležitostí souhry více faktorů. Jisté je jedno. Spravedlnost v tom nehledejme. Z Terentianova díla se např́klad připomíná jedině výše uvedený citát. Nic více. ${ }^{1}$

Ve svém příspěvku chci srovnat dvě práce, které se zabývají stejným tématem obecným správním právem. První knihou je proslulé Merklovo Obecné právo správní, ${ }^{2}$

Moudrost věků. Lexikon latinských výroků, přisloví a rčení. Praha, 1988, s. 223.

2 MERKL, A.: Allgemeines Verwaltungsrecht. Wien - Berlin, 1927. Český překlad, s nímž jsem pracoval a na který odkazuji: MERKL, A.: Obecné právo správní I-II. Praha - Brno, 1931-1932. O autorovi této knihy viz SCHAMBECK, H.: Merkl, Adolf Julius. In Neue Deutsche Biographie 17 (1994), s. 157 f. (Onlinefassung); URL: http://www.deutsche-biographie.de/pnd118581163.html. 
druhou pozapomenuté Pošvářovy Obecné pojmy správního práva. ${ }^{3}$ První je úctyhodná monografie přeložená do mnoha jazykủ, která ani dnes nesmí chybět v knihovně právního vědce. Druhá je drobným spiskem, spíše brožurou. Byla napsaná na sklonku druhé světové války bez možnosti použít ve větším rozsahu cizí literaturu a určená především studentům jako pomůcka po znovuotevření právnických fakult.

Každého pozorného čtenáře musí $\mathrm{v}$ souvislosti s takovým srovnáváním napadnout dvě otázky. Je taková komparace vůbec férová? A pak - co se tím vlastně získá? V odpovědi na první položený dotaz se nutně musí přiznat, že toto srovnání není př́liš spravedlivé. Tyto dvě knihy nepatří a ani nemohou patřit do stejné „váhové kategorie“. Nicméně porovnat je může být $\mathrm{v}$ mnoha ohledech užitečné. $\mathrm{V}$ první řadě proto, že obě jsou silně ovlivněny normativismem, tedy směrem kritickým a tvưrčím, navíc každá se hlásí $\mathrm{k}$ jeho jiné větvi, a nakonec docházejí $\mathrm{k}$ zajímavým výsledkům. Za druhé z toho důvodu, že jejich prostřednictvím lze sledovat, jak normativistická stanoviska pronikala do administrativistiky a jak se přitom osvědčila.

\section{INSPIRACE A VÝCHODISKA SROVNÁVANÝCH KNIH}

Už bylo řečeno, že společným ideovým východiskem obou zkoumaných prací je normativismus - Merklova kniha reprezentuje Vídeňskou ryzí nauku právní, Pošvářova kniha Brněnskou normativní právní teorii. Podívejme se tedy nyní ve stručném přehledu, co normativismus hlásal a o co mu v právní vědě šlo. Pozornost bude věnována styčným bodům obou jeho větví i tomu, co je rozdělovalo.

Normativismus se v právním myšlení a vědě etabloval v prvních desetiletích 20 . století jako kritický směr a mohutně expandoval. Byl reakcí na nedostatky právního pozitivismu. Zároveň však byl v jistém smyslu jeho dovršením. Velice nesmlouvavě vystupoval proti přirozenoprávním naukám a také proti sílícímu právněsociologickému směru. Oboje častoval výtkou nevědeckosti. ${ }^{4}$

Normativismus vybočil ze zaběhnutých kolejí právního myšlení hned ve dvou směrech. Snažil se dát právnímu myšlení pevný filozofický základ. Proto navazoval na některé interpretace I. Kanta. Usiloval rovněž o zvědečtění právního myšlení, které se podle něj utvářelo do té doby uzuálně nebo pod vlivem různých spekulací. $Z$ toho důvodu se věnoval hlavně gnozeologii a metodologii, stejně jako analýze právních pojmů. ${ }^{5}$

Normativismus byl orientován v linii novokantovství scientisticky, antimetafyzicky $\mathrm{a}$ antiideologicky. Jeho scientismus se projevoval v tom, že chtěl zvědečtit právní vědu očistou jejího předmětu, metody i terminologie. Ta se měla zabývat pouze právem (tedy ničím metanormativním), a to metodou zbavenou neprávních synkretismů, a měla pro-

3 POŠVÁŘ, J.: Obecné pojmy správního práva. Brno, 1946. K osobě a dílu tohoto autora viz např. VOJÁČEK, L.: Jaroslav Pošvár. In SKŘEJPKOVÁ, P. (ed.): Antologie československé právni vědy v meziválečném období (1918-1938). Praha, 2009, s. 472-475.

4 Přehledně WEYR, F.: Úvod do studia právnického (normativni theorie). Brno, 1946, s. 33 an., 40 an.

5 Stačí nahlédnout do základních prací normativistů - např. KELSEN, H.: Ryzí nauka právní. Metoda a základní pojmy. Brno - Praha, 1933. KELSEN, H.: Základy obecné teorie státni. Brno, 1926. WEYR, F.: Základy filosofie právni (nauka o poznávání právnickém). Brno, 1920. WEYR, F.: Teorie práva. Brno Praha, 1936. 
vést patřičnou „inventuru“ své terminologie. Antimetafyzický postoj spočíval v jeho odmítnutí řešit problém přirozeného práva a absolutní spravedlnosti. Antiideologické zaměření dával normativismus najevo zavrhováním vlivu ideologie na právo. ${ }^{6}$

Tuto svoji základní orientaci postavenou na Kantově učení, na dualismu bytí a mětí, poznání a chtění rozvíjely obě větve normativismu v gnozeologických a metodologických úvahách, v rozpracování stupňovité a dynamické koncepce práva, při strukturální analýze práva, jakož i při rozborech právní terminologie. Vedle značných překryvů však existovaly mezi oběma větvemi normativismu některé rozdíly. Brněnská škola navazovala na Kantovo učení v interpretaci Arthura Schoppenhauera, vídeňská pak v interpretaci marburské školy, zvláště Hermanna Cohena. Diference se týkaly pojetí právních norem, koncepce ohniska stupňovitě uspořádaného právního řádu i některých dílčích stanovisek ve věci interpretace práva a existence mezer v právu. ${ }^{7}$

Normativismus nebyl právní vědou ani představiteli ostatních společenských věd přijat jednoznačně. Odborná veřejnost se rozestoupila na jeho nadšené stoupence a zaryté odpůrce. Ti mu vyčítali př́lišnou abstraktnost, logicismus, ignorování společenských kořenů práva a terminologické experimenty (tedy nadřazení povinností právům, odstranění klasických dualismů v právu, pohlcení aplikace práva tvorbou práva a rozlišování norem obecných a konkrétních). Nicméně normativismu nelze upřít, že posunul dále výzkum struktury práva a neotřele se podíval na běžně uznávané pravdy. Sympaticky dodnes působí jeho antiideologický postoj, který byl kritikou podř́zení práva ideologii $\mathrm{v}$ totalitních režimech. ${ }^{8}$

Toto vše připomenout bylo nezbytné hlavně z důvodů srozumitelnosti dalšího výkladu. Pohlédneme-li př́mo do zkoumaných knih, zjistíme, že míra návaznosti na normativistické paradigma je v nich odlišná. I když se Merkl v zásadě drží stanovisek Vídeňské ryzí nauky právní, místy s Kelsenem neváhá polemizovat a také již na samotném začátku práce deklaruje snahu vyhýbat se „překotným novotám“ $.9 \mathrm{~V}$ předmluvě naznačuje, že navazuje na práce své i cizí.

Pošvár̆ nezastírá svou př́slušnost ke škole Brněnské normativní právní teorie, současně však připomíná, že tato škola budující „základy právnického myšlení narážela na četné filosofické problémy“. V souvislosti s tím pojmenovává jednu z jejích hlavních metodologických slabin: „Stačí uvědomiti si, že ryze juristické (normativní) hledisko je hlediskem formálním, které k obsahu přihlíží jen jako k náplni formy. Je hlediskem statickým, možno říci interpretačním. Poněvadž však nestačí k vyřešení různých otázek (nazývaných metajuristické - P. M.) ..., je nutno použíti ještě hledisek obsahových, jako hlediska de lege ferenda a hlediska dynamického (de lege applicata). Je ovšem bezpodmínečně nutno zachovávati přesně hranice všech těchto hledisek..." ${ }^{10} \mathrm{Z}$ těchto jeho slov je patrno, že si dobře uvědomoval problém metodologické redukce, s nímž se normati-

6 Viz BOGUSZAK, J.: Zásluhy a neúspěchy normativní teorie. In Misto normativní teorie v soudobém právním myšleni. Brno, 2003, s. 22.

7 Bliže KUBEŠ, V.: Brněnská škola ryzí nauky právní. In WEINBERGER, O. - KUBEŠ, V. (eds.): Brněnská škola právni teorie (normativni teorie). Praha, 2003, s. 10.

$8 \mathrm{~K}$ tomu důkladně PINZ, J.: Normativní teorie - splendidní soustava právního myšlení. In Místo normativní teorie..., s. 29 a 33 an.

9 MERKL, Obecné právo správní I..., s. 1.

10 POŠVÁR̆ Obecné pojmy..., s. 8. 
vismus potýkal. Věděl rovněž, že jeho vyřešení vyústí v popření postulátu ryzosti, tedy v opuštění jednoho ze základních východisek normativismu. V rámci možností se pak Pošvář snaží tohoto nedostatku vyvarovat, i když ne vždy úplně čistě. Dokládá to první část jeho práce nazvaná $\mathrm{O}$ právu.

Míra návaznosti na základní východiska normativismu je v obou spisech patrná v obecných i speciálních tématech. Prozatím se soustřed’me na témata nejobecnější, speciálnější záležitosti přijdou na řadu později. Zajímat nás bude, jak obě práce definují stát a právo.

Podle Merkla je stát v nejobecnějším smyslu kvalifikovanou organizací, totiž právní organizací. Jde o souhrn orgánů uskutečňujících právní rád. Stát však neztotožňuje s právním řádem jako Kelsen. Tvrdí jen, že stát a právní řád jsou nerozlučitelné. Nekryjí se, ale jsou na sobě závislé. Právo chápe jako souhrn všech právních pravidel (norem) donucovací povahy, jako stupňovitě uspořádaný právní řád. V tomto směru se od Kelsena neliší. ${ }^{11}$

Zajímavé jsou některé jeho názory upřesňující pojem a funkci státu. Zdůrazňuje, že stát je v činnosti udržován centrálním fondem, který čerpá své př́ijmy ze zvláštních právně upravených zdrojů (definice státu $v$ užším smyslu) ${ }^{12}$ a že je protipólem samosprávy (definice státu v nejužším smyslu). ${ }^{13} \mathrm{Z}$ funkcionálního hlediska nahlíží na stát jako na prostř̌edek k plnění jakýchkoli sociálních účelů. ${ }^{14}$

Pošvář věnuje pojmu práva daleko větši prostor než Merkl. Obecnými výklady o právu jeho kniha začíná, zatímco Merkl se pojmy práva a státu zabývá na pozadí správní problematiky. Právo vymezuje Pošvář jako ,rrád upravující určité vzájemné vztahy jednotlivců $\mathrm{v}$ určitém společenském celku“. Tomuto řádu přičítá několik podstatných vlastností: regulativnost zajištěnou normami, hierarchičnost, trvalost opírající se hlavně o sankce, platnost a uznání ze strany podřízených subjektů. Toto je právo v obecném, objektivním a formálním smyslu (právní rád de lege lata). Od něj je tř̌eba odlišovat oprávnění - právo v konkrétním, subjektivním a obsahovém smyslu (právní raád de lege applicata). Oprávnění pojímá jako rub plnění povinností. ${ }^{15}$ Jak je vidět na první pohled, Pošvář se od názorů Brněnské normativní právní teorie, reprezentované v první řadě F. Weyrem, poněkud odchyluje a jde vlastní cestou - ve směru výše uvedené kritiky. Naopak víceméně recipuje argumenty brněnských normativistů proti rozlišování soukromého a veřejného práva. Poukazuje na nepřesnost běžných způsobů rozlišování, na relativitu rozdílů mezi těmito oblastmi práva. Uzavírá, že rozdíl mezi soukromým a veřejným právem asi nejlépe vyjadřuje jurisdikce: $\mathrm{v}$ soukromoprávních věcech rozhoduje soud, ve veřejnoprávních věcech správa. Vedle toho zohledňuje, jak v dané oblasti vzniká právo - v soukromém právu autonomně, ve veřejném heteronomně. ${ }^{16}$

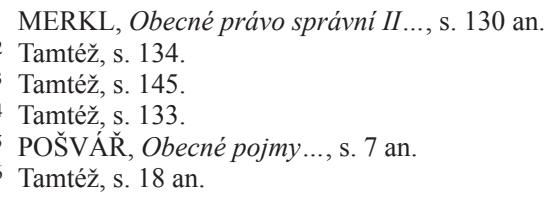


O státu píše Pošvář jen jako o jediném a hlavním subjektu veřejné správy, ostatní subjekty veřejné správy od něj odvozují svoji subjektivitu. ${ }^{17}$ Bližší analýzu této instituce v knize nepodává.

\section{SPRÁVNĚPRÁVNÍ PROBLEMATIKA V MERKLOVĚ A POŠVÁŘOVĚ KNIZE}

Přejděme k správněprávní problematice, jíž se obě knihy zabývají především. Merklovo dílo je bez diskuze tematicky i zpracováním komplexnější. Pokrývá veškerá podstatná témata týkající se teoretických základů správního práva. Zaměřuje se na základní pojmy nauky o správním právu, právní rád správy, formy správní činnosti, obsah správní činnosti, organizaci správy a kontrolu správy.

Pošvářova kniha je o poznání skromnější - jak výběrem témat, tak co do zpracování. Po části první věnované obecným výkladům o právu následuje část druhá zabývající se správou a část třetí zacílená na správní právo. Zatímco Merklova práce má ráz monografický, Pošvářova vykazuje charakter propedeutický. Nehledě na to i Pošvářova kniha zaujme zařazením některých subkapitol povahy právněteoretické - interpretace a aplikace správního práva, meze platnosti správního práva.

Východiskem obou knih je definice správy. Merkl se drží většinového názoru, který ztotožňuje správu s hospodářstvím, resp. podřazuje hospodářskou činnost správě. Tomu Pošvář oponuje. Tvrdí, že ,hospodářství je sice správa, avšak každá správa není hospodářství“. Správa je podle něj ,prostředkem, formou, jíž se hospodářství provádí“. Domnívá se, že správa není pojmem hospodářským, ale správně-politickým. Jde o činnost spojující v sobě prvek právní (podřízenost právu) a účelový (sleduje záměrné dosažení nějakého cíle). ${ }^{18} \mathrm{~V}$ rozlišování na správu soukromou a veřejnou vládne shoda. Pošvář výstižně definuje rozdíl mezi nimi: první se vyznačuje autonomií a menší vázaností právem, druhá heteronomií a větší vázaností právem, jakož i tvorbou sekundárních norem. ${ }^{19}$

Veřejnou správu vymezují oba autoři prakticky stejně - na bázi formální a negativní definice: vše, co obstarává stát mimo zákonodárství a justice. Rozhraničení zákonodárství a správy je relativní, stejně jako rozlišení tvorby a aplikace práva. Zákonodárství se jeví jako výkon ústavy, správa jako výkon zákonů. Rozdíl mezi správou a justicí je větší: ve funkcích a orgánech. Justice je nalézáním práva osobami, které jsou relativně nezávislé, správa spočívá ve výkonné činnosti orgánů, které nejsou nezávislé. Společně jsou správa a justice výkonem zákonů, jsou tedy protipólem zákonodárství, a dochází v nich k vydávání sekundárních aktů (mnohdy konkrétních).

I když oba autoři používají stejných nebo podobných argumentů, Pošvář více sází na formální rozlišování mezi správou a ostatními složkami státní moci. K materiálním rozdílům doporučuje přihlížet subsidiárně. ${ }^{20}$ Merklův pohled je samozřejmě hlubší -

\footnotetext{
17 Tamtéž, s. 36.

18 Tamtéž, s. 24 an.

19 Tamtéž, s. 26 an.

20 MERKL, Obecné právo správní I..., s. 3 an. POŠVÁ̌̆, Obecné pojmy..., s. 31 an.
} 
zabývá se i rozdílem mezi správou a vládou. Tu také podřizuje zákonům, nechápe ji jako činnost nevázanou, ale jako souhrn správních funkcí nejvyšších správních orgánů. ${ }^{21}$ Důkladný je i jeho výklad o hlavních dějinných typech správy. Sleduje hlavně posun od policejního absolutistického státu nevázaného zákony (tedy státu bez správního práva) k modernímu právnímu státu podřizenému zákonům (tedy státu se správním právem). Ten existuje ve dvou variantách: justiční stát, kompetenčně upřednostňující justici, a správní stát, dávající přednost správě. Pozornost věnuje též modernímu policejnímu státu v radikálních demokraciích a extrémních oligarchiích. ${ }^{22}$

Výklad o rozdělení veřejné správy je u obou autorů kompatibilní. Oba vycházejí z klasického rozlišování správy na vnitřní, zahraniční, vojenskou, finanční a justiční a ukazují jejich překryvy. Poukazují také na historické proměny pojmu policie: od všezahrnující správní činnosti k bezpečnostní složce. ${ }^{23}$ Další rozlišení, kterému se obě práce věnují, je dělení na státní správu a samosprávu. Shodně připomínají některé organizační a funkcionální rozdíly mezi nimi: ve státní správě převažuje princip monokratického rozhodování, jmenování při obsazování funkcí, centralizace a princip byrokratický, v samosprávě pak princip kolegiálního rozhodování, volební, decentralizační a účasti občanstva. ${ }^{24}$

Merkl se navíc zabývá vztahem správy a státní formy. Výrazem demokracie ve správě je kolegiální rozhodování, obsazování funkcí volbou a samospráva. Autokracie se ve správě projevuje monokratickým rozhodováním a jmenovacím principem. Demokratická správa se vyznačuje větší pružností, přizpůsobivostí, ale také nepřesnou aplikací zákonů, nadvládou politiků odtržených od národa a politizací správy. Autokratickou správu sice zdobí přesnější aplikace zákonů, naproti tomu ji zatěžuje odcizenost životu a nebezpečí byrokratismu. Pro demokracii je podle Merkla nejdůležitější důsledné provádění zákonů, parlament by také neměl rozhodovat proti vưli lidu. I v demokracii je autokratický prvek ve správě nutný a svým způsobem prospěšný. ${ }^{25}$

Stejně jako správě věnují se oba spisy i správnímu právu a jeho aplikaci. Podle Merkla je správa funkcí správního práva. ${ }^{26}$ Podrobně se zabývá jeho prameny. Rozhodující význam přičítá zákonům (zásada přednosti zákona), zmiňuje i expanzi mezinárodního práva do práva vnitrostátního. Správní praxi může podstatně ovlivnit i správní a soudní obyčej. ${ }^{27}$ Za druhý nejvýznamnější pramen správního práva po zákonu ale pokládá nařízení. Dělí je na právní a správní. Připomíná rovněž specifika správního práva - to, že pro rozsah, různorodost a nutnost pružnosti není (s výjimkou správního procesu) kodifikováno ${ }^{28}$ a že se vyznačuje širokou mírou uvážení. Tyto jeho vlastnosti staví do částečného protikladu s justičním právem. Rozdíl mezi nimi se podle něj vy-

\footnotetext{
MERKL, Obecné právo správní I..., s. 47 an.

Tamtéž, s. 64 an.

MERKL, Obecné právo správni II.., s. 59 an. POŠVÁr̆, Obecné pojmy..., s. 43 an.

MERKL, Obecné právo správni II..., s. 150 an., 188 an. POŠVÁR̆, Obecné pojmy..., s. 50 an.

MERKL, Obecné právo správni II..., s. 177 an.

MERKL, Obecné právo správní I..., s. 95 an.

Tamtéž, s. 104 an.

Tamtéž, s. 128 an.
} 
rovnává teprve postupně. ${ }^{29}$ Názory Pošváře se od Merklových nijak podstatně neliší, až na to, že vše konfrontuje s právovědou francouzskou a italskou. ${ }^{30}$

Správní právo je částí stupňovitě uspořádaného právního řádu. Reguluje organizaci a činnost veřejné správy (státu a dalších odvozených subjektů veřejné správy - veřejnoprávních korporací, podniků a ústavů), jakož i veřejné subjektivní povinnosti a práva. ${ }^{31}$ Podle Merkla by správa bez správního práva nemohla existovat. Při své činnosti se musí pohybovat v zákonných mezích. ${ }^{32}$ To platí pro akty právotvorné (nařízení i rozhodnutí) i exekutivní. Opak zakládá nicotnost nebo odporovatelnost. Merkl je pro striktní přístup, protože přehlížení vad nebo jejich zhojení podvrací právo. ${ }^{33}$ Právní moc přísluší jen aktům bezvadným. ${ }^{34}$ Ani zde se Pošvářovy závěry od Merklových mnoho neliší, jen zohledňují existenci ještě jiné literatury než německé a rakouské. ${ }^{35}$

V samostatných kapitolách je v obou knihách pojednáno o správním řízení, o správním právu trestním a správní exekuci. Většinou autorům jde o nalezení shod a rozdílů $\mathrm{s}$ řízením před soudy, resp. se soudním trestáním a vynucováním povinností. Konstatováno je zmenšování rozdílů mezi správou a justicí a větší operativnost správy. ${ }^{36}$ Rozdíl mezi správním a soudním právem trestním je shledán nejprve jen v kompetenci, pak i v zavinění a trestech. ${ }^{37}$ Výklad o správním právu trestním a správní exekuci potvrzuje sankční a donucovací povahu správního práva. ${ }^{38}$

Závěr Merklova díla je věnován kontrole správy. Tato kapitola však u Pošváře zcela chybí. Prostréedky kontroly správy jsou rozlišovány na imanentní a transcendentní. Posledně jmenované Merkl dělí na politické, účetní a právní. ${ }^{39}$ Těžiště výkladu se pak týká správního soudnictví.

\section{ZÁVĚR}

Ve svém prŕíspěvku jsem se pokusil srovnat dvě knihy: proslulé Merklovo Obecné právo správní a pozapomenuté Pošvářovy Obecné pojmy správního práva. Má-li se celá komparace shrnout, nezbývá než konstatovat, že obě práce mají vysokou úroveň a plně vyhovovaly účelům, kvůli nimž vznikly. Rozdíly mezi nimi jsou dané hlavně jejich rozsahem, důkladností zpracování a okolnostmi, za kterých byly napsány. Z hlediska obsahového lze zaznamenat některé názorové neshody. Společné však měly normativistické východisko, které následovaly nedogmaticky. I dnes mohou být zdrojem poučení a inspirace, přestože je svět a správní věda o mnoho dále. ${ }^{40}$

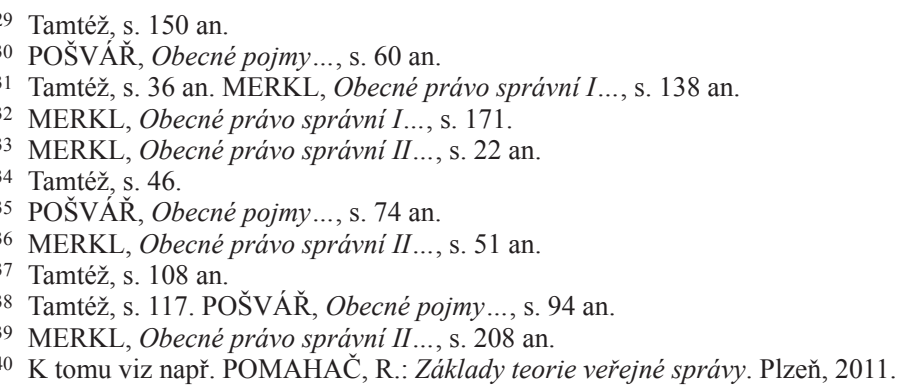


Nadčasovost obou knih plyne z kritického př́istupu autorů a z jejich schopnosti vypořádat se s nástrahami zpracování správního práva. Ty popsal v jedné ze svých publikací čelný představitel brněnského normativismu F. Weyr. ${ }^{41}$ První komplikací správního práva je neuvěřitelný rozsah správní materie a její různorodost, jakož i proměnlivost. To nejen problematizuje zobecnění, ale i takřka vylučuje zvládnutí celého tohoto právního odvětví jedním člověkem. Druhým úskalím je vztah mezi správním a ústavním právem, které od sebe nejsou zcela odděleny. Ústavní právo se týká základních zásad činnosti státu a ostatních veřejnoprávních korporací, správní právo stanoví podrobná pravidla fungování těchto celků. Jde o to nalézt mezi těmito vrstvami právního řádu při výkladu vyvážený poměr. Třetím momentem ztěžujícím zpracování jsou přesahy správního práva do ostatních odvětví právního řádu a sklon některých správněprávních agend stát se samostatným právním odvětvím, což správní právo nežádoucím způsobem oslabuje a celé právo partikularizuje. Nicméně tyto těžkosti autorům nezabránily provést zamýšlenou syntézu správněprávní problematiky. Spíše asi působily jako výzva k jejímu vykonání.

I když skutečnou proslulost a vliv na další vývoj právního myšlení a vědy mělo jen dílo Merklovo, ani Pošvářovu práci nelze podceňovat - alespoň u nás ne. ${ }^{42}$ Merklova kniha měla kromě př́znivců také více oponentů a kritiků. Významný český administrativista J. Hoetzel na její adresu jízlivě poznamenal, že byla zvláště u nás přeceněna. ${ }^{43}$ Od důsledného stoupence klasického právního pozitivismu a předního odpůrce normativismu ale nebylo možné očekávat nic jiného.

Doc. JUDr. PhDr. Pavel Maršálek, Ph.D.

Univerzita Karlova, Právnická fakulta

marsalep@prf.cuni.cz

41 WEYR, F.: Československé právo správni. Část obecná. Brno, 1922, s. 3 an.

42 Viz MIKULE, V.: Správní právo v českých zemích (curriculum vitae). In Právnická fakulta Univerzity Karlovy 1348-1998. Praha, 1998, s. 88 an.

43 HOETZEL, J.: Československé správni právo. Část všeobecná. Praha, 1937, s. 70. 